\title{
Consequences of Bank Distress During the Great Depression
}

\author{
By Charles W. Calomiris and Joseph R. Mason*
}

The consequences of bank distress for the economy during the Depression remain an area of unresolved controversy. Since John M. Keynes (1931) and Irving Fisher (1933), macroeconomists have argued that bank distress magnified the extent of the economic decline during the Depression. As the intermediaries controlling money and credit, banks were in a special position to transmit their distress to other sectors. But the mechanism through which banking distress mattered for the economy has been hotly contested.

Milton Friedman and Anna J. Schwartz (1963) saw the contraction in the money multiplier-driven, in their view, by panicked depositors' withdrawals of deposits - as the primary mechanism through which banking distress affected the real economy. They described the mechanism transmitting banking distress to the real sector as operating at the national level through changes in the aggregate supply of money and interest rates. Bank distress reduced the money supply available to the public either through the closure of banks and the consequent freezing of bank deposits, or the withdrawals of deposits by depositors that feared bank failure.

Ben S. Bernanke (1983), building on Fisher (1933), emphasized the transmission of monetary shocks via their effects on the balance sheets of borrowers and on the supply of credit by banks. Borrowers' balance sheets were worsened by debt deflation as the result of fixed

\footnotetext{
* Calomiris: Graduate School of Business, 601 Uris Hall, Columbia University, 3022 Broadway, New York, NY 10027, and National Bureau of Economic Research (e-mail: cc374@columbia.edu); Mason: Department of Finance, Drexel University, 3141 Chestnut Street, Philadelphia, PA 19104 (e-mail: joe.mason@drexel.edu). We thank Valerie Ramey, David Wheelock, Charles Himmelberg, Steve Zeldes, Gary Gorton, two referees, and seminar participants at Columbia University, Wharton, Northwestern University and the 2001 Economic History Association Meetings for helpful comments on an earlier draft. We gratefully acknowledge support from the National Science Foundation, the University of Illinois, and the Federal Reserve Bank of St. Louis.
}

dollar debt obligations-borrowers' net worth and cash flow declined with the rising value of debt service costs relative to income. Borrowers with positive net present value projects, but weak balance sheets, had less internally generated retained earnings to invest and could not qualify for credit. Furthermore, Bernanke argued that the contraction of the money supply produced contraction of nominal income and prices relative to fixed debt service, which weakened borrowers' balance sheets, and in turn, weakened banks.

Not only did firms' financial distress reduce the number of qualified borrowers, the contraction in banks' net worth forced a reduction in the supply of bank loans to qualified borrowers. Many firms and individuals relied on banks for credit, and as those banks suffered losses of capital (due to asset value declines) and contractions in deposits (as depositors reacted to bank weakness by withdrawing their funds), even borrowers with viable projects and strong balance sheets experienced a decrease in the effective supply of loanable funds.

Bernanke termed the combined weakening of borrowers' balance sheets and the contraction in bank credit supply a rise in the "cost of credit intermediation." The scarcity of perfect substitutes for the positive net present value investments of firms with weak balance sheets, and for the credit supplied by existing banks, implies that the weakening of firms' and banks' balance sheets, the disappearance of banks, and the contraction in surviving banks' lending made it more difficult for the economy to channel funds to their best use. Thus, what began as a contraction in aggregate demand became a contraction in aggregate supply, which magnified adverse economic shocks and prolonged and deepened the Depression. The financial distress of firms and banks, and the decline in bank lending, were not only symptoms of the Depression, but means for magnifying the shocks that caused the Depression. Bernanke's statistical evidence in support of this story is derived from time-series analysis at the national level, in 
particular his regression analysis relating bank failures, business failures, and deflation to subsequent output contraction, after taking into account money contraction.

Some have challenged Bernanke's view empirically, arguing that existing macroeconomic time-series evidence does not necessarily indicate that borrower creditworthiness and bank credit supply were important channels for magnifying shocks. Many of the empirical criticisms of the Bernanke approach focus on the difficulty of separating credit-supply shocks from endogenous declines in the demand for credit. ${ }^{1}$ Call the first critique the loan-demand critique. Proponents of this critique argue that an aggregate decline in bank credit, like that which occurred during the Depression, does not necessarily imply a decline in bank credit supply due to weak bank balance sheets. Instead, it may simply indicate a lack of viable projects for firms to pursue in a depressed economy. A decline in bank lending may reflect a contraction in loan demand in anticipation of, or simultaneous with, contractions in output. Thus, the fact that loan contraction accompanies or precedes output contraction does not necessarily imply a causal connection running from financial distress and loan supply to output. The loan-demand critique was a point of view that found support during the 1930's (see Charles O. Hardy and Jacob Viner, 1935, and Lewis H.

\footnotetext{
${ }^{1} \mathrm{We}$ do not provide a detailed review of the various theoretical and empirical arguments for and against the Bernanke view. For a review of some of that literature, see Peter Temin (1989), Calomiris (1993), Calomiris and Berry Wilson (1998), and Ali Anari et al. (2002). The most recent paper challenging the Bernanke view is Harold L. Cole and Lee E. Ohanian (2000). Their evidence is indirect and of questionable relevance to the debate over the role of bank loan supply during the Depression. They do not model or measure bank loan supply, but rather argue from evidence on the deposit-output ratio that banking "services" (meaning deposits) were not in scarce supply. In their empirical work, they do not focus on bank lending, per se. In that sense, their evidence is not very relevant for the debate over the role of bank lending during the Depression. They do examine data on interest rate and bond spreads and corporate dividends and claim that they see little evidence of credit supply contraction from these data. This is not the place to contest their discussion of those data. We would simply point out here that they only employ very indirect and aggregate measures that they argue are linked to credit supply, broadly defined, and that their study does not attempt to measure the effect of bank credit supply on economic activity.
}

Kimmel, 1939). To address the loan-demand critique, one must identify sources of loan supply as distinct from loan demand.

A second critique of Bernanke was developed by Hugh Rockoff (1993), which we will call the "quality-of-money" critique. Rockoff shows that Bernanke's evidence of the importance of bank and business failures for aggregate economic activity is not robust to the inclusion of other time-series variables in the regression. Rockoff constructs a measure of the qualityadjusted money supply, which takes account of the fact that deposits in suspended banks were not perfect substitutes for nonsuspended deposits as a form of money. He finds that including his measure of quality-adjusted money in the Bernanke empirical specification avoids any need for additional, nonmonetary explanatory variables. Rockoff's point, more generally, is that another aggregate time-series variable with unusually large spikes confined to the same limited periods of time as the Bernanke explanatory variables (1929-1933) can take explanatory power away from Bernanke's measures.

The goal of this paper is to consider tests of the Bernanke view that take into account the loan-demand and quality-of-money critiques. Our starting point is the insight that disaggregation is a promising means of identification. Our strategy is to devise empirical tests using disaggregated data (at the state level and county level) that can distinguish between Bernanke's interpretation of his findings and the interpretations offered by critics. The quality-of-money critique is an argument about an aggregate effect in the market for money. By exploiting cross-sectional variation, we are able to control for that, and other, aggregate channels of influence. To address the loan-demand critique, we identify local loan-supply shocks by combining the framework developed by Bernanke (1983) and Calomiris and Wilson (1998), which links adverse shocks to bank condition to future bank loan supply, with Calomiris and Mason's (2000) empirical analysis of the determinants of bank distress during the Depression. We then link loan-supply shocks to subsequent income growth.

The remainder of this paper is organized as follows. Section I describes the data set. Section II investigates the linkages at the state and county levels between bank distress and eco- 
Table 1 -Variable Definitions and Conditional Means

\begin{tabular}{|c|c|c|c|c|}
\hline Annual state-level and county-level data & Level & $N$ & Mean & $\begin{array}{l}\text { Standard } \\
\text { deviation }\end{array}$ \\
\hline $\begin{array}{l}\text { Growth in production income over relevant period } \\
\text { (log difference) }\end{array}$ & State & 47 & -0.473 & 0.089 \\
\hline \multirow{2}{*}{$\begin{array}{l}\text { Growth in bank deposits from end of } 1930 \text { to end } \\
\text { of } 1932 \text { (log difference) }\end{array}$} & State & 47 & -0.367 & 0.180 \\
\hline & County & 116 & -0.344 & 0.234 \\
\hline $\begin{array}{l}\text { Growth in bank loans from end of } 1930 \text { to end of } \\
1932 \text { (log difference) }\end{array}$ & State & 47 & -0.430 & 0.179 \\
\hline $\begin{array}{l}\text { Growth in liabilities of failed businesses over } \\
\text { relevant period (log difference) }\end{array}$ & State & 47 & 0.196 & 0.529 \\
\hline \multirow{2}{*}{$\begin{array}{l}\text { Growth in building permits over relevant period } \\
\text { (log difference) }\end{array}$} & State & 45 & -1.380 & 0.490 \\
\hline & County & 116 & -1.526 & 0.645 \\
\hline $\begin{array}{l}\text { Growth in total value of building permits granted } \\
\text { from fourth quarter } 1928 \text { to fourth quarter } 1929 \\
\text { (log difference) }\end{array}$ & County & 116 & -0.365 & 0.631 \\
\hline \multirow[t]{2}{*}{$\log ($ total bank assets in 1929) } & State & 47 & 6.655 & 0.794 \\
\hline & County & 116 & 15.285 & 0.968 \\
\hline \multirow[t]{2}{*}{ Real estate owned in 1929/noncash assets in 1929} & State & 48 & 0.011 & 0.008 \\
\hline & County & 116 & 0.009 & 0.010 \\
\hline \multirow{2}{*}{$\begin{array}{l}(\text { Capital }+ \text { surplus }+ \text { undivided profits }+ \\
\text { contingency reserve in 1929)/total assets in } 1929\end{array}$} & State & 47 & 0.339 & 0.197 \\
\hline & County & 116 & 0.143 & 0.035 \\
\hline $\begin{array}{l}\text { Value of new building permits within the state for } \\
\text { 1930/state income in } 1929\end{array}$ & State & 46 & 0.016 & 0.010 \\
\hline $\begin{array}{l}\text { Liabilities of failed businesses for 1930/state } \\
\text { income in } 1929\end{array}$ & State & 48 & 0.008 & 0.004 \\
\hline
\end{tabular}

Note: Zero observations are omitted from summary statistics.

nomic activity, describes our approach to identifying cross-sectional loan-supply shocks, and examines the effects of cross-sectional bank loan-supply shocks on income at the state and county levels over the period 1930-1932. Our county-level analysis uses the growth in building permits as an indicator of economic activity. Section III summarizes our results and concludes.

\section{Data}

Our data set is constructed from bank-level, state-level, and county-level observations. In this section, we describe the definitions and sources for our data, which are summarized in Table 1.

Our bank-level data are from the database created by Calomiris and Mason (2000). In that paper, we describe our method for assembling bank-level balance sheet and income statement data from microfilm records of "call reports" of all Federal Reserve member banks, which we used to forecast bank distress (see Mason, 1998, for an overview of the call report data we col- lected, and Calomiris and Mason, 1997, 2000, for our results on predicting bank distress). Calomiris and Mason (1997, 2000) find that many characteristics of individual banks and their local economic environments are useful for forecasting bank distress even during periods of widespread financial distress. For our purposes here, however, we limit our forecasting variables to loan-supply instruments-variables that, on ex ante grounds, are likely to be more closely associated with loan supply than with loan demand. In Section II, we argue that bank size, real estate owned relative to loans, and bank net worth relative to assets-all measured as of December 1929 — are good loansupply instruments.

In our state-level regression analysis, we use bank-level data to construct only one of our three state-level instruments. Real estate owned relative to loans is derived from individual Federal Reserve member bank-level data from Calomiris and Mason (2000). Bank-level data on real estate owned relative to loans is aggregated at the state level by weighting each bank's observation by its proportion of Fed member 
bank deposits in the state. We then adjust our state-level measures of this ratio for Fed member banks to control for the presence of non-Fed member banks, under the assumption that Fed member banks and non-Fed member banks within any state had similar ratios of real estate owned relative to loans.

In our state-level regression analysis, the remaining two instruments, and additional statelevel measures of bank characteristics and economic activity, are from other data sources. Average bank size (assets per bank) and the ratio of net worth to total assets are from the Federal Reserve Board's All Bank Statistics (1959). This is also the source for annual statelevel data on bank loans and deposits. Annual state-level data on production income are taken from John A. Slaughter (1937). State-level annual data on building permits and the liabilities of commercial failures are constructed from Bradstreet's Weekly and Dun's Review, respectively. Annual data on liabilities of failed businesses are reported directly. Data on building permits at the state level are not reported directly. Bradstreet's reports monthly data on the dollar value of new construction (building expenditures for which permits are granted) for a set of 215 cities in the United States. We aggregated these up to the state level annually to provide an annual index for each state.

Our measures of state-level deposit and loan growth are for the period from the end of 1930 to the end of 1932, as are our measures of state-level income. We measure bank condition at the end of 1929, and loan, deposit, and income growth from the end of 1930 until the end of 1932. In doing so, we limit problems of simultaneity and capture intertemporal linkages among early bank distress and subsequent growth in deposits, lending, and economic activity.

We end our sample period at the end of 1932. The trough of the Great Depression was March 1933, so that year-end 1932 approximates the trough of the Depression, both from the standpoint of economic activity and the health of the banking sector (see Calomiris and Mason, 2000, for a more complete discussion of changes in bank condition over time).

Our county-level analysis constructs measures of our loan-supply instruments (bank asset size, net worth to assets, and real estate owned) by taking simple averages of individual banklevel data for these variables within the county. County-level data on bank loans are not available from any source of which we are aware, but aggregate bank deposits at the county level are reported by the Federal Deposit Insurance Corporation in its Data on Banks in the United States, 1920-1936 (1992).

There are no measures of income at the county level of which we are aware. But the value of building permits is reported for each of 215 cities in the United States. We employ the growth in the value of building permits from 1930 to 1932 as a measure of growth in economic activity in the county in which that city is located. ${ }^{2}$ It is difficult to know how closely building permits track overall economic activity. Building permit data are not available at the state level, to our knowledge, and in many states an aggregation of building permits data from major cities would likely give a distorted picture of building activity for the state as a whole (particularly, for agricultural states). Given these problems, we are encouraged by the fact that the correlation between annual state income growth and the state-level aggregate of annual growth in the value of city building permits is reasonably high during our sample period $(0.54)$.

\footnotetext{
${ }^{2}$ For 49 of the 215 cities for which monthly building permits data are reported, Bradstreet's reports incomplete data (that is, one or more months in which no data are given). It is not clear whether the value of building permits was zero in these months or simply not reported. In some cases, some cities did report zero values for monthly building permits, thus the failure to report the data may be indicative of missing data rather than no building permits. In the state-level, annual building permit aggregates, we treat missing values as zeros because missing values are rare and the errors induced from the absence of data are likely to have a small effect on state-level aggregates. In the countylevel data, however, we omit these cities and their surrounding counties from our analysis, since we lack confidence in our county-level measures for those counties. For 33 other cities, we experienced various idiosyncratic problems matching cities to counties in a comparable way, and so we omitted those cities and counties from our county-level analysis as well. Eighteen cities in our sample lie within the same counties as one or more of the other 215 cities in the sample. In that case, we take the sum of building permits in all cities located within a given county as our measure of building permits in the county. These three factors result in a county-level sample size of 116 counties.
} 
Table 2-OLS and 2SLS Regressions, Dependent Variable: State-LeVel Income Growth, 1930-1932

\begin{tabular}{|c|c|c|c|c|c|c|}
\hline \multirow{2}{*}{$\frac{\text { Estimation method }}{\text { Constant }}$} & \multicolumn{2}{|c|}{ OLS } & \multicolumn{2}{|c|}{$\begin{array}{c}\text { 2SLS using instrumented } \\
\text { deposit growth, } \\
\text { 1930-1932 }\end{array}$} & \multicolumn{2}{|c|}{$\begin{array}{l}\text { 2SLS using instrumented } \\
\text { loan growth, } \\
1930-1932\end{array}$} \\
\hline & $\begin{array}{l}-0.294 * * * \\
(0.036)\end{array}$ & $\begin{array}{l}-0.336 * * * \\
(0.048)\end{array}$ & $\begin{array}{l}-0.282^{* * * *} \\
(0.053)\end{array}$ & $\begin{array}{l}-0.310 * * * \\
(0.057)\end{array}$ & $\begin{array}{l}-0.300 * * * \\
(0.054)\end{array}$ & $\begin{array}{l}-0.279 * * * \\
(0.089)\end{array}$ \\
\hline $\begin{array}{l}\text { Growth in production income over } \\
1929-1930 \text { (log difference) }\end{array}$ & $\begin{array}{c}0.058 \\
(0.149)\end{array}$ & $\begin{array}{c}0.038 \\
(0.200)\end{array}$ & & $\begin{array}{c}0.052 \\
(0.142)\end{array}$ & & $\begin{array}{l}0.008 \\
(0.211)\end{array}$ \\
\hline $\begin{array}{l}\text { Growth in bank deposits from end of } \\
1930 \text { to end of } 1932 \text { (log difference) }\end{array}$ & $\begin{array}{l}0.468^{* * * *} \\
(0.073)\end{array}$ & & $\begin{array}{l}0.522 * * * \\
(0.140)\end{array}$ & $\begin{array}{l}0.484 * * * \\
(0.124)\end{array}$ & & \\
\hline $\begin{array}{l}\text { Growth in bank loans from end of } 1930 \\
\text { to end of } 1932 \text { (log difference) }\end{array}$ & & $\begin{array}{l}0.233 * * * \\
(0.080)\end{array}$ & & & $\begin{array}{l}0.403 * * * \\
(0.121)\end{array}$ & $\begin{array}{l}0.448 * * * \\
(0.157)\end{array}$ \\
\hline $\begin{array}{l}\text { Growth in building permits over } 1930- \\
1932 \text { (log difference) }\end{array}$ & $\begin{array}{c}0.004 \\
(0.021)\end{array}$ & $\begin{array}{c}0.017 \\
(0.027)\end{array}$ & & $\begin{array}{c}-0.609 \\
(1.117)\end{array}$ & & $\begin{array}{c}-0.961 \\
(1.670)\end{array}$ \\
\hline $\begin{array}{l}\text { Growth in liabilities of failed businesses } \\
\text { over 1930-1932 (log difference) }\end{array}$ & $\begin{array}{r}-0.022 \\
(0.019)\end{array}$ & $\begin{array}{r}-0.038^{*} \\
(0.025)\end{array}$ & & $\begin{array}{l}2.697 \\
(2.580)\end{array}$ & & $\begin{array}{l}2.313 \\
(3.786)\end{array}$ \\
\hline $\begin{array}{l}\text { Number of observations } \\
\text { Adiusted } R^{2}\end{array}$ & 45 & 45 & 47 & 45 & $\begin{array}{r}47 \\
0\end{array}$ & 45 \\
\hline Adjusted $R^{2}$ & 0.493 & 0.156 & 0.220 & 0.298 & 0.179 & 0.148 \\
\hline
\end{tabular}

Note: Standard errors are in parentheses. State-level income growth is defined as the growth in annual production income between the years 1930 and 1932 (log difference). Predicting equations for loan growth and deposit growth are reported in Table 3.

* Statistically significant at the 10 -percent level.

** Statistically significant at the 5-percent level.

*** Statistically significant at the 1-percent level.

\section{Identifying Loan-Supply Effects}

Table 2 reports partial correlations from ordinary least-squares (OLS) regressions that relate state-level income growth-measured from the end of 1930 to the end of 1932 - to statelevel deposit growth, loan growth, building activity, and business failures over the period from the end of 1930 to the end of 1932. As Table 2 shows, state-level deposit and loan growth during 1931 and 1932 are associated with income growth, even after controlling for lagged income growth (during 1930) and for contemporaneous building activity and business failures (which also have significant partial correlations with state-level income growth). ${ }^{3}$

These OLS regressions provide evidence of association between state-level variation in bank deposits or loans and state-level variation

\footnotetext{
${ }^{3}$ In results not reported here, we also investigated intertemporal linkages at the state level between annual loan growth and annual income growth using a panel VAR regression framework with one lag. We found that loans and income Granger cause each other.
}

in income that cannot be explained by the quality-of-money critique. That critique relies upon a monetary interpretation of the transmission mechanism of shocks during the Great Depression in which the quality-adjusted aggregate money supply displaces the aggregate supply of bank loans as an explanatory variable. While variation in loan supply and demand, and in money demand, should be associated with variation in income locally as well as in the aggregate, money-supply variation is captured by the constant term in the regressions, since it is an aggregate influence. There was a national market for money (in which reserves and cash are transferred across regions easily), and thus, there should have been no state-level variation in the supply of money.

Under the U.S. unit banking system and dual chartering laws (for state and national banks), in contrast, the supply of bank credit was local; banks located in other parts of the country (which lacked the information and customer contacts of local banks) could not provide perfect substitutes for local bank credit. Thus, disaggregation within the United States offers a promising approach for assessing the 
importance of the Bernanke view because of the geographic isolation that was peculiar to American banking. ${ }^{4}$

Nevertheless, the OLS regressions in Table 2 say nothing about the effects of bank loansupply shocks, per se, on economic activity. Bank balance sheets may grow or shrink alongside economic activity simply as the result of endogenous changes in money demand or loan demand. Identifying the loan-supply effect requires one to show that influences emanating from loan supply, per se, mattered for output.

Our approach to identifying the effects of local loan-supply shocks is to posit loan-supply instruments-variables that produce variation in loan supply during the early 1930's that is exogenous with respect to state-level income variation in the early 1930's (and therefore, unrelated to loan-demand or money-demand shocks) - and then use those instruments to link identified loan-supply shocks to variation in local income.

Microeconomic evidence suggests that reductions in the value of bank assets were an important source of variation for bank loan supply. Calomiris and Mason $(1997,2000)$ and Calomiris and Wilson (1998) show that adverse shocks to banks' asset values, combined with depositor preferences for liquidity and low risk, caused banks to contract the supply of loans in the 1930's. That evidence suggests that exogenous variation in loan supply was driven in large part by bank distress. Bank distress raised funding costs and reduced deposits, leading banks to reallocate assets toward cash and curtail loan supply.

Not all predictors of bank distress are suitable as loan-supply instruments. Many of the variables that forecast distress are likely to be associated with both loan-supply and loandemand shocks faced by a bank. For example, local building activity, local commercial distress, and banks' loan-to-asset ratios are predictors of distress that are likely to be governed by both loan-supply and loan-demand variation. We identify three variables as loan-supply instruments: bank size, real estate owned relative to loans (a standard measure of previous loan

\footnotetext{
${ }^{4}$ See Calomiris (2000) for a review of the history of unit banking restrictions and their costs.
}

foreclosures), and bank net worth relative to total assets. All of these variables are measured as of the end of 1929, before the shocks of the Great Depression had produced changes in bank loan foreclosures and net worth. Cross-sectional variation in average bank size mainly reflects state-level differences in banking regulation, geography, and demography. Differences in loan foreclosures and net worth as of 1929 mainly reflect the extent to which banks were exposed to losses on some classes of agricultural loans during the 1920 's. We assume that none of these three measures is likely to be correlated with loan-demand variation during the period 1930-1932. In part, that assumption reflects the fact that the shocks of the Great Depression (and the loan-demand changes produced by those shocks) were not merely a continuation of the shocks of the 1920's. If there were serial correlation in shocks, then the case for using the real estate owned and bank net worth variables would be weakened. Historical analyses of the shocks of the 1920's and those of the Great Depression suggest that, in fact, the origins of these disturbances were quite different (see Calomiris, 1992; Calomiris and Mason, 2000). ${ }^{5}$

Our approach to identifying loan supply is summarized diagrammatically in Figure 1. The key assumption of our analysis is the exogeneity of the instruments. In Figure 1 this is illustrated by the absence of arrows flowing from either loan demand or economic activity over the period 1930-1932 to the three loan-supply instruments (bank size, the bank net worth ratio, and real estate owned relative to assets, all in 1929). Table 3 presents our regression results for the first-stage regression in which the three instruments predict loan and deposit growth over the period from the end of 1930 until the end of 1932.

Table 2 reports our two-stage least-squares regressions identifying the effect of loan supply on income growth at the state level. Here loan

\footnotetext{
${ }^{5}$ In results not reported here, we also included other forecasting variables in our instrument list and obtained similar results. But those other variables, although also measured in 1929, are not as desirable as instruments. Some of those variables include bank balance sheet ratios or measures of contemporaneous local economic conditions, both of which are likely to be correlated with loan demand.
} 


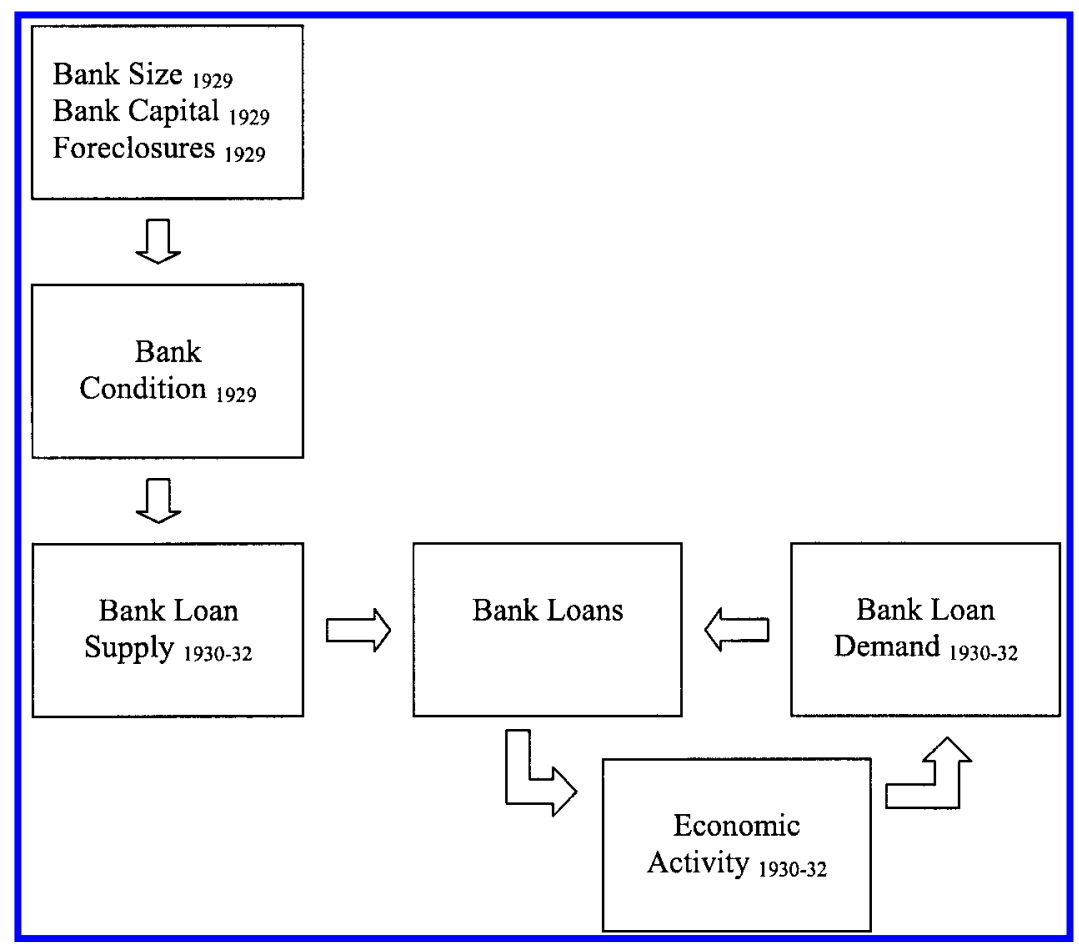

Figure 1. IDENTIFYING LOAN-SUPPLy EFFECTS

TABle 3-Predicting OLS REgRESSIONS, Dependent Variables: State-Level Deposit Growth AND LOAN GROWTH, 1930-1932

\begin{tabular}{lcc}
\hline \hline Estimation method & OLS & OLS \\
Dependent variable & $\begin{array}{c}\text { Deposit growth } \\
\text { Loan growth } \\
\end{array}$ & $\begin{array}{c}1930-1932 \\
1930-1932\end{array}$ \\
\hline Constant & $-0.774 * * *$ & $-0.794 * * *$ \\
& $(0.258)$ & $(0.233)$ \\
log(total bank assets in 1929) & $0.056 *$ & $0.062 * *$ \\
& $(0.035)$ & $(0.032)$ \\
Real estate owned in & -3.954 & $-8.321 * * *$ \\
$\quad$ 1929/noncash assets in 1929 & $(3.629)$ & $(3.282)$ \\
(Capital + surplus + undivided & $0.232^{* *}$ & 0.125 \\
profits + contingency reserve & $(0.127)$ & $(0.115)$ \\
$\quad$ in 1929)/total assets in 1929 & & \\
\hline Number of observations & 47 & 47 \\
Adjusted $R^{2}$ & 0.201 & 0.335 \\
\hline
\end{tabular}

Note: Standard errors are in parentheses.

* Statistically significant at the 10-percent level.

** Statistically significant at the 5-percent level.

**** Statistically significant at the 1-percent level.

supply is captured through the instrumented changes in loans or deposits. In our analysis of loan-supply effects we also include, as controls, various measures of economic activity in 1930, including income growth from 1929 to 1930, liabilities of failed businesses in 1930, and building permits in 1930 .

We find that instrumented loan growth and deposit growth (alternative measures of the loan-supply effect) have significant explanatory power for cross-sectional variation in state income in 1930-1932. In the specifications that include controls for income growth in 1930 and measures of building activity and commercial distress in 1930, the results are similar. These results are supportive of an important lending channel, which explains the links between cross-sectional variation in income growth and deposit and loan growth at the state level. Bank distress-induced contractions in credit supply seem to have played an important role in statelevel income growth during the Depression. At the mean of our sample, a one-standarddeviation (17.9 percent) decrease in loan-supply growth over our period produced roughly a 7-percent decline in income over the same period (using instrumented loans as the measure of loan-supply effects). If one uses instrumented 


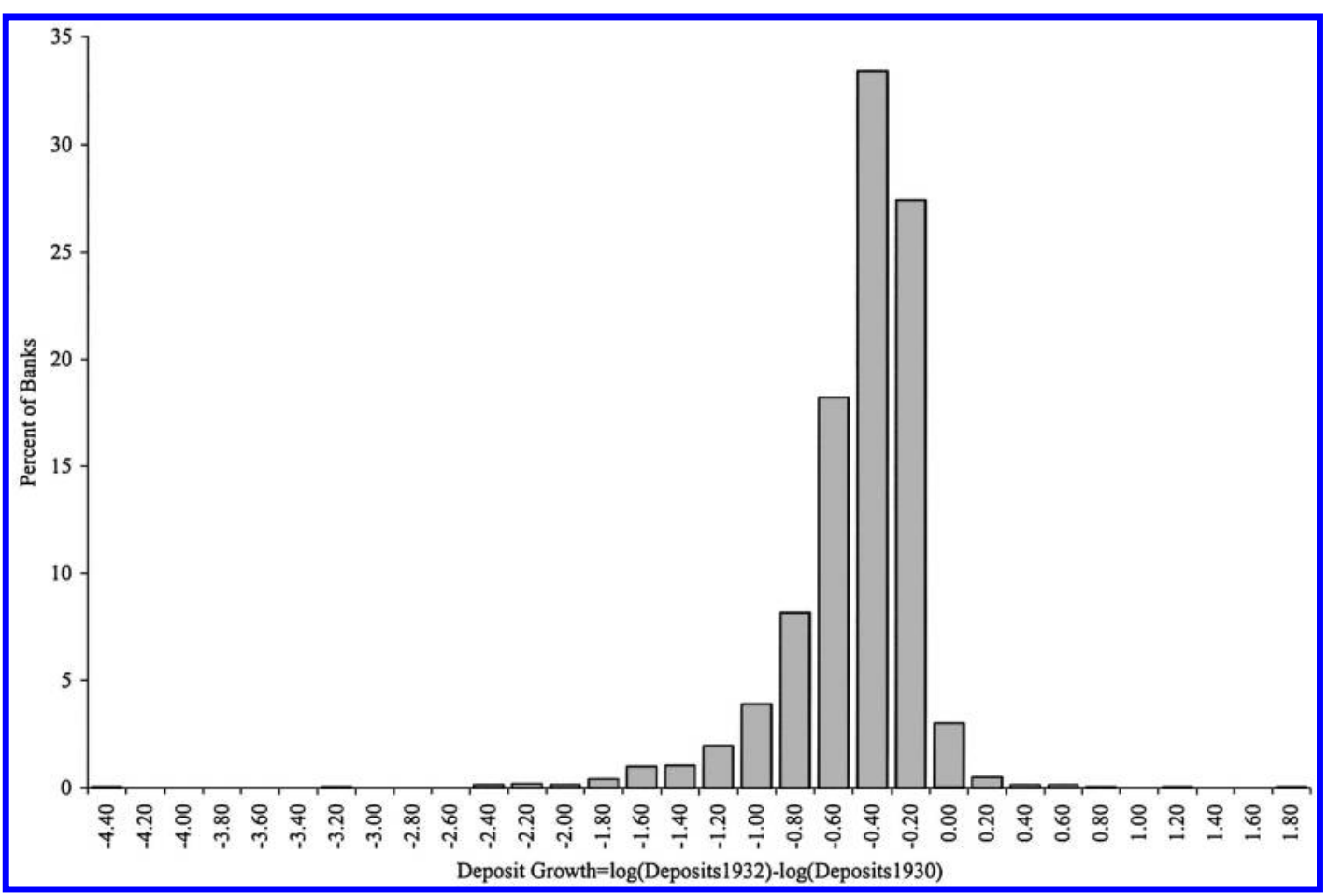

Figure 2. Histogram of County-Level Deposit Growth Distribution, 1930-1932

deposits to measure the loan-supply effect, the analogous effect on income is a decline of around 9 percent.

One of the limitations of our state-level analysis is the small number of observations. Furthermore, it is possible that state-level aggregation masks important local variation in the supply of credit and in economic activity. A simple ANOVA analysis of deposit growth from 1930 to 1932 at the county level indicates that only 17 percent of the variation in countylevel deposit growth is captured by crosssectional variation in state-level deposit growth. Most (83 percent) of the variation in countylevel deposit growth is attributable to withinstate variation. Figures 2 and 3 plot histograms of the growth rate of deposits at the state and county levels. To improve sample size, and to check for the robustness of our findings at a higher level of disaggregation, we investigate the links between loan-supply shifts and economic activity at the county level.

As discussed in Section I, building permits (reported for 215 cities) are an indicator of economic activity at the county level for counties in which major cities are located. Table 4 reports county-level results analogous to those in Table 2, linking deposit growth and economic activity over the period 1930-1932. As Table 4 shows, deposit growth and building permit growth are positively related at the county level.

In Table 5, we employ county-level loansupply instruments, analogous to those used in Table 3, to predict deposit growth at the county level. We find that the net worth ratio and bank size measure enter with the predicted positive signs and are statistically significant as predictors of deposit growth. In Table 4, two-stage least-squares regressions analogous to those in Table 2 are reported. We find that, as in our state-level results, loan-supply shocks have large and statistically significant effects on economic activity at the county level. At the sample mean, a loan-supply shock producing a one-standard-deviation (23.4-percent) 


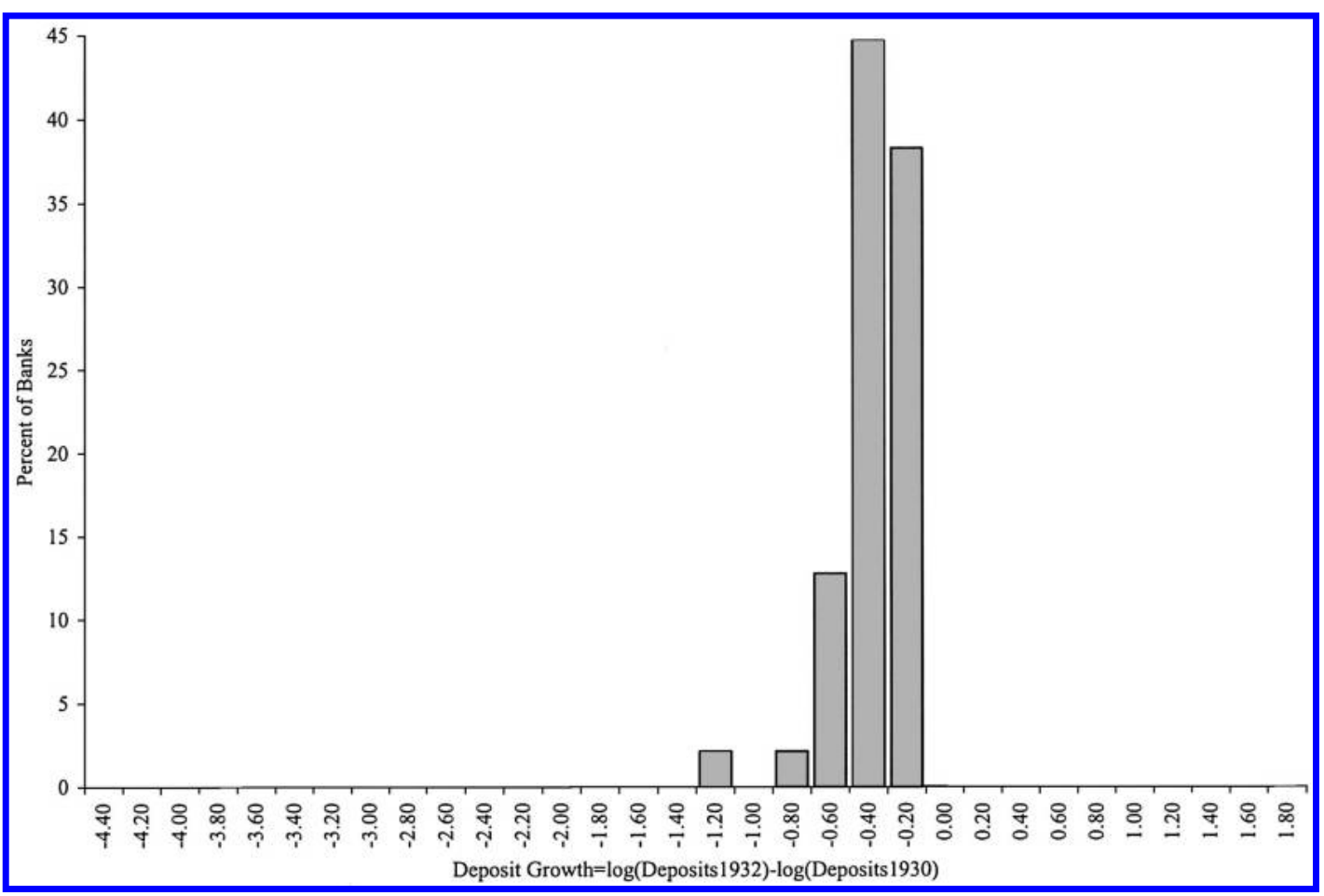

Figure 3. Histogram of State-Level Deposit Growth Distribution, 1930-1932

TABle 4-OLS and 2SLS Regressions, Dependent Variable: County-Level Building Permit Growth for 131 Major Cities, 1930-1932

\begin{tabular}{lcc}
\hline \hline & & $\begin{array}{c}\text { 2SLS using instrumented } \\
\text { deposit growth, } \\
1930-1932\end{array}$ \\
\hline Estimation method & OLS & -0.531 \\
Constant & $-1.157 * * *$ & $(0.419)$ \\
Growth in total value of building permits & $(0.103)$ & -0.001 \\
$\quad$ granted in county from fourth quarter of 1928 & $(0.088)$ & $(0.109)$ \\
$\quad$ to fourth quarter of 1929 (log difference) & & $2.891 * * *$ \\
Growth in bank deposits in county from end of & $1.099 * * *$ & $(1.179)$ \\
$\quad$ 1930 to end of 1932 (log difference) & $(0.235)$ & 116 \\
\hline Number of observations & 116 & 0.035 \\
Adjusted $R^{2}$ & 0.149 & \\
\hline
\end{tabular}

Note: Standard errors are in parentheses. Building permit growth is defined as the growth in total building permits granted annually between the year 1930 and 1932 (log difference). Predicting equation for deposit growth is reported in Table 5. Sample size is explained in footnote 2.

* Statistically significant at the 10-percent level.

** Statistically significant at the 5-percent level.

*** Statistically significant at the 1-percent level.

decline in deposits results in a 67.7-percent decline in the county-level value of building permits. The fact that the size of the loan-supply effect is so much larger for building permits likely reflects the high cyclical volatility of the construction sector and its 
TABle 5-Predicting OLS Regression, Dependent Variable: County-Level Deposit Growth, 1930-1932

\begin{tabular}{lc}
\hline \hline Estimation method & OLS \\
Dependent variable & $\begin{array}{c}\text { Deposit growth } \\
1930-1932\end{array}$ \\
\hline Constant & $-1.333 * * *$ \\
& $(0.389)$ \\
log(total bank assets in 1929) & $0.052^{* *}$ \\
& $(0.023)$ \\
Real estate owned in & 0.701 \\
1929/noncash assets in 1929 & $(2.229)$ \\
(Capital + surplus + undivided & $1.263 * *$ \\
profits + contingency reserve & $(0.628)$ \\
in 1929)/total assets in 1929 & \\
\hline Number of observations & 116 \\
Adjusted $R^{2}$ & 0.037 \\
\hline
\end{tabular}

Note: Standard errors are in parentheses.

* Statistically significant at the 10-percent level.

** Statistically significant at the 5-percent level.

*** Statistically significant at the 1-percent level.

sensitivity to conditions in local credit markets.

\section{Conclusion}

We examine the effects of banking distress on the real sector during the Great Depression. We investigate whether banking distress was an important propagator of shocks that originated elsewhere in the economy, through a loansupply channel.

Loan-supply instruments-forecasters of bank distress that are not likely to be highly correlated with loan-demand variation across states-are useful for explaining cross-state variation in income growth during 1931 and 1932. Our evidence indicates that variation in the supply of bank credit explains a substantial amount of the variation in state income growth over this period. Our county-level analysis of the effect of loan-supply shocks on the growth in the value of building permits over the same period corroborates the statelevel findings.

\section{REFERENCES}

Anari, Ali; Kolari, James and Mason, Joseph R. "Bank Asset Liquidation and the Propagation of the U.S. Great Depression." Wharton Financial Institutions Center (Philadelphia, PA) Working Paper No. 02-35, August 2002.

Bernanke, Ben S. "Nonmonetary Effects of the Financial Crisis in the Propagation of the Great Depression." American Economic Review, June 1983, 73(3), pp. 257-76.

Calomiris, Charles W. "Do Vulnerable Economies Need Deposit Insurance? Lessons from U.S. Agriculture in the 1920's," in Philip L. Brock, ed., If Texas were Chile: A primer on bank regulation. San Francisco, CA: Sequoia Institute, 1992, pp. 237-349, 450-58. . "Financial Factors in the Great Depression." Journal of Economic Perspectives, Spring 1993, 7(2), pp. 61-85. . U.S. bank deregulation in historical perspective. Cambridge: Cambridge University Press, 2000.

Calomiris, Charles W. and Mason, Joseph R. "Contagion and Bank Failures During the Great Depression: The June 1932 Chicago Banking Panic." American Economic Review, December 1997, 87(5), pp. 863-83. - "Causes of Bank Distress During the Great Depression." National Bureau of Economic Research (Cambridge, MA) Working Paper No. 7919, September 2000.

Calomiris, Charles W. and Wilson, Berry. "Bank Capital and Portfolio Management: The 1930's 'Capital Crunch' and Scramble to Shed Risk." National Bureau of Economic Research (Cambridge, MA) Working Paper No. 6649, July 1998; Journal of Business (forthcoming).

Cole, Harold L. and Ohanian, Lee E. "ReExamining the Contributions of Money and Banking Shocks to the U.S. Great Depression," in Ben S. Bernanke and Kenneth Rogoff, eds., NBER macroeconomics annual 2000. Cambridge, MA: MIT Press, 2000, pp. 183-226.

Federal Deposit Insurance Corporation. Data on banks in the United States, 1920-1936. Ann Arbor, MI: Inter-University Consortium for Political and Social Research Study No. 00007, 1992.

Federal Reserve Board. All bank statistics. Washington, DC: Board of Governors, 1959.

-Fisher, Irving. "The Debt-Deflation Theory of the Great Depression." Econometrica, October 1933, 1(4), pp. 337-57. 
Friedman, Milton and Schwartz, Anna J. A monetary history of the United States, 1867-1960. Princeton, NJ: Princeton University Press, 1963.

Hardy, Charles O. and Viner, Jacob. Report on the availability of bank credit in the Seventh Federal Reserve District. Washington, DC: U.S. Government Printing Office, 1935.

Keynes, John M. "The Consequences to the Banks of the Collapse of Money Values." Essays in persuasion. New York: W.W. Norton, 1963; previously published: 1931.

Kimmel, Lewis $\mathbf{H}$. The availability of credit, 1933-1938. New York: National Industrial Conference Board, Inc, 1939.

Mason, Joseph R. "American Banks During the Great Depression: A New Research Agenda."
Federal Reserve Bank of St. Louis Review, May/June 1998, 80(3), pp. 151-52. - "Do Lender of Last Resort Policies Matter? The Effects of Reconstruction Finance Corporation Assistance to Banks During the Great Depression." Journal of Financial Services Research, September 2000, 20(1), pp. 77-95.

Rockoff, Hugh. "The Meaning of Money in the Great Depression." National Bureau of Economic Research (Cambridge, MA) Historical Paper No. 52, December 1993.

Slaughter, John A. Income received in the various states, 1929-1935. New York: National Industrial Conference Board Studies, No. 234, 1937.

Temin, Peter. Lessons from the Great Depression. Cambridge, MA: MIT Press, 1989. 


\section{This article has been cited by:}

1. Simon Gilchrist, Egon Zakrajšek. 2011. Monetary Policy and Credit Supply Shocks. IMF Economic Review 59:2, 195-232. [CrossRef]

2. Ken B. Cyree, Pinghsun Huang, James T. Lindley. 2011. The Economic Consequences of Banks' Derivatives Use in Good Times and Bad Times. Journal of Financial Services Research . [CrossRef]

3. R. Iyer, J.-L. Peydro. 2011. Interbank Contagion at Work: Evidence from a Natural Experiment. Review of Financial Studies 24:4, 1337-1377. [CrossRef]

4. Barry Eichengreen. 2011. Crisis and Growth in the Advanced Economies: What We Know, What We Do not, and What We Can Learn from the 1930s. Comparative Economic Studies . [CrossRef]

5. NAOAKI MINAMIHASHI. 2011. Credit Crunch Caused by Bank Failures and Self-Selection Behavior in Lending Markets. Journal of Money, Credit and Banking 43:1, 133-161. [CrossRef]

6. Masami Imai, , Seitaro Takarabe. 2011. Bank Integration and Transmission of Financial Shocks: Evidence from JapanBank Integration and Transmission of Financial Shocks: Evidence from Japan. American Economic Journal: Macroeconomics 3:1, 155-183. [Abstract] [View PDF article] [PDF with links]

7. Robert D. Baller, Phil Levchak, Mark Schultz. 2010. "The Great Transformation" and Suicide: Local and Long-Lasting Effects of 1930 Bank Suspensions. Suicide and Life-Threatening Behavior 40:6, 574-586. [CrossRef]

8. C. W. Calomiris. 2010. The political lessons of Depression-era banking reform. Oxford Review of Economic Policy 26:3, 540-560. [CrossRef]

9. N. Crafts, P. Fearon. 2010. Lessons from the 1930s Great Depression. Oxford Review of Economic Policy 26:3, 285-317. [CrossRef]

10. MARK CARLSON. 2010. Alternatives for Distressed Banks during the Great Depression. Journal of Money, Credit and Banking 42:2-3, 421-441. [CrossRef]

11. Barrie A. WigmoreA comparison of federal financial remediation in the great depression and 2008-2009 27, 255-303. [CrossRef]

12. Luc Laeven, Ross Levine. 2009. Bank governance, regulation and risk taking\#. Journal of Financial Economics 93:2, 259-275. [CrossRef]

13. Charles W Calomiris. 2009. The Subprime Turmoil: What's Old, What's New, and What's Next. The Journal of Structured Finance 15:1, 6-52. [CrossRef]

14. Brandon R. Dupont. 2009. Panic in the plains: agricultural markets and the panic of 1893. Cliometrica 3:1, 27-54. [CrossRef]

15. DANIEL PARAVISINI. 2008. Local Bank Financial Constraints and Firm Access to External Finance. The Journal of Finance 63:5, 2161-2193. [CrossRef]

16. Asim Ijaz Khwaja, , Atif Mian. 2008. Tracing the Impact of Bank Liquidity Shocks: Evidence from an Emerging MarketTracing the Impact of Bank Liquidity Shocks: Evidence from an Emerging Market. American Economic Review 98:4, 1413-1442. [Abstract] [View PDF article] [PDF with links]

17. Peter Temin. 2008. Real Business Cycle Views of the Great Depression and Recent Events: A Review of Timothy J. Kehoe and Edward C. Prescott's Great Depressions of the Twentieth CenturyReal Business Cycle Views of the Great Depression and Recent Events: A Review of Timothy J. Kehoe and Edward C. Prescott's Great Depressions of the Twentieth Century. Journal of Economic Literature 46:3, 669-684. [Abstract] [View PDF article] [PDF with links] 
18. VIRAL V. ACHARYA, TANJU YORULMAZER. 2008. Information Contagion and Bank Herding. Journal of Money, Credit and Banking 40:1, 215-231. [CrossRef]

19. R HUANG. 2007. Evaluating the real effect of bank branching deregulation: Comparing contiguous counties across US state borders\#. Journal of Financial Economics . [CrossRef]

20. Sherrill Shaffer. 2007. Aggregate concentration and the cost of systemic risk. Applied Economics Letters 14:6, 425-428. [CrossRef]

21. Gregor W. Smith. 2006. The spectre of deflation: a review of empirical evidence. Canadian Journal of Economics/Revue canadienne d'economique 39:4, 1041-1072. [CrossRef]

22. THOMAS F. CARGILL, THOMAS MAYER. 2006. The Effect of Changes in Reserve Requirements During the 1930s: The Evidence from Nonmember Banks. The Journal of Economic History 66:02. . [CrossRef]

23. Adam B. Ashcraft. 2005. Are Banks Really Special? New Evidence from the FDIC-Induced Failure of Healthy BanksAre Banks Really Special? New Evidence from the FDIC-Induced Failure of Healthy Banks. American Economic Review 95:5, 1712-1730. [Abstract] [View PDF article] [PDF with links]

24. Joseph R. Mason. 2005. A Real Options Approach to Bankruptcy Costs: Evidence from Failed Commercial Banks During the 1990s. The Journal of Business 78:4, 1523-1554. [CrossRef] 